\title{
Financial Development and International Trade
}

\author{
Fernando Leibovici ${ }^{1}$ \\ New York University
}

JOB MARKET PAPER

January 13, 2013

[Download latest version]

\section{ABSTRACT}

This paper studies the extent to which frictions in financial markets affect aggregate trade flows. I study a model of firm dynamics with financial frictions and international trade, calibrated to match key features of firm-level data. I find that, while financial frictions have a large effect on the pattern and extent of international trade at the industry-level, as documented in the literature, they have a small effect on trade at the aggregate-level. Relaxing the financial constraints allows more firms to finance the upfront export entry costs, with a significant impact on industry-level trade flows to the extent that the industry is small enough to affect equilibrium prices. In contrast, removing the financial constraints at the aggregate-level leads to an increase in the wage and interest rate, thereby reducing the returns to becoming an exporter, with a small impact on aggregate trade flows. I also find that the cross-industry response of international trade to financial development is quantitatively consistent with industry-level evidence on the extent of trade across countries, and that the effectiveness of policies aimed at increasing trade by easing the access to credit for exporters is limited if implemented at an economy-wide scale.

\footnotetext{
${ }^{1}$ Email: fernando.leibovici@nyu.edu. Website: http://files.nyu.edu/fml234/public/. Mailing address: 19 West 4th St, 6th floor, NYC, 10012 NY. I would like to thank Virgiliu Midrigan, Mike Waugh, Gian Luca Clementi, Jonathan Eaton, David Backus, Kim Ruhl, Ana Maria Santacreu, David Kohn, Michal Szkup, Gaston Navarro, Håkon Tretvoll, and Andres Zambrano for their helpful feedback and suggestions.
} 


\section{Introduction}

International trade costs are large, particularly in developing countries ${ }^{2}$. While recent studies have estimated large gains from reducing these costs in poor countries ${ }^{3}$, an important challenge is to identify the policies that may allow poor countries to reduce them. A recent literature has suggested that financial constraints play a key role in distorting aggregate trade flows in financially underdeveloped countries $^{4}$, acting as a potentially important cost to international trade.

A salient feature of the data is that countries with less developed financial markets export a relatively smaller fraction of their GDP. A key channel through which financial frictions affect international trade flows at the industry level is by distorting firms' export entry decisions ${ }^{5}$. In this paper, I use firm-level data to quantitatively study the extent to which financial frictions distort firms' export entry decisions and lower international trade flows at the aggregate level in a general equilibrium framework.

I study a model of firm dynamics with international trade, financial frictions, and upfront export entry costs, and calibrate it to match key features of firm-level data. I find that differences in the magnitude of financial frictions cannot account for the relationship between financial development and international trade observed in the data at the aggregate level, even though they do predict a strong industry-level relationship as documented in the literature. While relaxing the financial constraint leads more firms to afford the costs required to start exporting, factor prices increase in equilibrium, reducing the returns to becoming an exporter. A higher level of financial development allows all constrained firms to expand, not just exporters - this increases the demand for labor and debt, driving up the wage and interest rate, and lowering the return to exporting. In contrast, removing financial constraints for an individual industry has a significant impact on that industry's trade share to the extent to which the industry is too small to affect equilibrium prices.

The model consists of an economy populated by heterogeneous firms subject to financial constraints and international trade costs. Firms are born with an idiosyncratic level of productivity and a low initial level of capital. Financial frictions take the form of a collateral constraint, with the amount of credit available to firms limited by the value of capital that can serve as collateral at the time that

\footnotetext{
${ }^{2}$ Anderson and van Wincoop (2004).

${ }^{3}$ Waugh (2010) shows that there can be large gains for poor countries from reducing their international trade costs to the level of richer countries.

${ }^{4}$ Manova (forthcoming), Beck (2002).

${ }^{5}$ Manova (forthcoming).
} 
loans are repaid ${ }^{6}$. Moreover, firms can trade internationally, but need to pay a sunk export entry cost a period before they can start to export, as well as an ad-valorem trade cost per unit that is sold abroad $^{7}$.

Financial frictions distort the firms' decision to start exporting through two channels. First, firms with a sufficiently low capital stock cannot generate sufficient internal funds to pay for the sunk export entry cost, and don't have enough collateral to finance it externally. Second, firms that can afford to start exporting may still operate at a sub-optimal scale upon entry to the export market if their capital stock is sufficiently low, reducing the returns to exporting. In addition, at low levels of capital, firms face a high opportunity cost to paying the export entry cost, since they could use those resources to increase their production scale. Thus, financial frictions increase the costs and reduce the returns to exporting for firms with low capital, leading them to choose not to export.

I calibrate the model to match key features of firm-level data from the Chilean Manufacturing Survey for the period 1995-2007. The model is calibrated to match firm-level moments informative about the differences between exporters and non-exporters, as well as features of the firms' life-cycle dynamics that are informative of their financial constraint. The model is also calibrated to match the level of credit and trade at the aggregate level. I find that the model can also account for features of the data not targeted in the calibration strategy, which are key to the mechanism that I study. In particular, I find that the model can account for moments that are informative of distortions to firms' export decisions along both the extensive and intensive margins.

I then use the calibrated model as a laboratory to study the extent to which financial frictions distort firms' export entry decisions and lower international trade flows at the aggregate level. To do so, I compare simulated data from the calibrated model to that from a model without financial frictions. I find that financial development does not lead to an economically significant increase in the share of GDP that is exported at the aggregate level.

Even though relaxing the financial constraint would allow more firms to trade internationally, the equilibrium wage and interest rate increase thereby reducing the returns to becoming an exporter. Thus, trade does not increase relative to total production as financial constraints are relaxed. To show

\footnotetext{
${ }^{6}$ For related closed-economy models of heterogeneous firms subject to financial constraints, see Midrigan and Xu (2012), Buera, Kaboski, and Shin (2011), and Buera and Moll (2012).

${ }^{7}$ International trade is modeled following Melitz (2003) and Chaney (2008), and the dynamic features of Alessandria and Choi (2012).
} 
this, I contrast these results with those obtained by keeping the equilibrium wage and interest rate fixed at their pre-financial-development level. I interpret these results as reflecting the effect of removing financial constraints in a small industry. I find that, in this case, the relative level of international trade does increase considerably. Therefore, general equilibrium effects offset a key mechanism through which financial development can lead countries to trade relatively more.

While recent studies have interpreted the strong cross-sectoral relationship between financial development and international trade as evidence of a link between them at the aggregate level, my findings suggest otherwise. For instance, Manova (forthcoming) documents that sectors with higher "external finance dependence" 8 feature relatively higher international trade flows in countries that are more financially developed. She finds that the relationship observed in the data can be largely accounted by distortions to firms' export entry and sales decisions due to financial frictions. Furthermore, she interprets her findings to suggest that financial development may have played a key role in accounting for the growth of aggregate exports across countries over recent decades.

In contrast, my findings suggest that firm- or sectoral-level evidence on the relationship between finance and international trade need not imply a link between them at the aggregate level. To evaluate this conjecture, I extend the model to feature two sectors heterogeneous in the collateralizability of the capital stock. I use this extension of the model to study the quantitative potential of financial underdevelopment to account for the cross-sectoral relationship between finance and international trade documented in the literature. I find that, even though financial development leads to a small increase in the relative level of international trade at the aggregate level, it can lead to much larger changes at the sectoral level. Thus, these findings show that, while financial underdevelopment may lower the relative level of trade at the sectoral level, it need not affect it at the aggregate level.

Similarly, a recent empirical literature has documented that financial factors are important in accounting for firms' export entry decisions, suggesting that financial frictions may distort aggregate trade flows ${ }^{9}$. Using Italian data, Minetti and Zhu (2011) show that "credit rationed" firms are less likely to export and, to the extent that they do, they are likely to export less. In a similar spirit, Bellone, Musso, Nesta, and Schiavo (2010) report a negative relationship between firms' "financial

\footnotetext{
${ }^{8}$ Sectors with high external finance dependence are interpreted to require a relatively more intensive use of external finance. For details, see Rajan and Zingales (1998).

${ }^{9}$ For quantitative studies of the role of financial frictions in accounting for firms' export decisions, see Kohn, Leibovici, and Szkup (2012) and Gross and Verani (2012).
} 
health" and both their export status and export intensity. Suwantaradon (2012) uses data from the World Bank Enterprise Survey to show that firms with higher net worth are more likely to export. My findings suggest that this evidence need not have implications for the share of aggregate output that is exported. In my model, while financial factors play a key role in accounting for the decisions of firms, these do not affect the relative level of trade at the aggregate level.

The remainder of the paper is organized as follows. Section 2 presents the model. Section 3 discusses how the model works, and the mechanism through which financial frictions distort aggregate trade flows and output. Section 4 presents the quantitative analysis of the model. Section 5 examines the cross-sectoral implications of the model. Section 6 concludes.

\section{Model}

I now present the model that I use to study the relationship between financial development and international trade. The model consists of an economy populated by unit measures of entrepreneurs and final good producers who trade with the rest of the world. Entrepreneurs operate a firm that produces a differentiated intermediate good and supply a unit of labor inelastically. Final good producers produce final goods using domestic and imported intermediates, which entrepreneurs use for consumption and investment. The rest of the world demands goods from entrepreneurs, and supplies imported intermediate goods to final good producers.

\subsection{Final good producer}

Final good producers purchase domestic and imported intermediate goods, and aggregate them to produce a final good. To do so, they operate a constant elasticity of substitution (CES) technology, with elasticity of substitution $\sigma>1$. Given prices $\left\{p_{D}(i)\right\}_{i \in[0,1]}$ and $p_{M}$ charged by domestic entrepreneurs and the rest of the world, they choose the bundle of inputs of domestic and imported intermediates $\left\{y_{D}(i)\right\}_{i \in[0,1]}$ and $y_{M}$ that maximizes their profits. Then, the final good producer's problem can be 
represented by the following problem:

$$
\begin{aligned}
& \max _{y_{D}(i), y_{M}} p y-\int_{0}^{1} p_{D}(i) y_{D}(i) d i-p_{M} y_{M} \\
& \text { subject to } \\
& y=\left[\int_{0}^{1} y_{D}(i)^{\frac{\sigma-1}{\sigma}} d i+y_{M}^{\frac{\sigma-1}{\sigma}}\right]^{\frac{\sigma}{\sigma-1}},
\end{aligned}
$$

where $p$ and $y$ are the price and quantity of the final good, respectively.

Given prices $\left\{p_{D}(i)\right\}_{i \in[0,1]}$, and $p_{M}$, the quantity of each intermediate good demanded by final good producers is given by the following demand functions:

$$
\begin{aligned}
y_{D}(i) & =\left[\frac{p_{D}(i)}{p}\right]^{-\sigma} y, \\
y_{M} & =\left[\frac{p_{M}}{p}\right]^{-\sigma} y
\end{aligned}
$$

where these are the demand functions faced by domestic entrepreneurs and the rest of the world.

\subsection{Entrepreneurs}

Preferences Entrepreneurs are risk averse, with preferences over streams of consumption of final goods represented by the lifetime discounted sum of a constant relative risk aversion (CRRA) period utility function:

$$
U\left(\left\{c_{t}\right\}_{t=0}^{\infty}\right)=\sum_{t=0}^{\infty}[\beta(1-\nu)]^{t} \frac{c_{t}^{1-\gamma}}{1-\gamma},
$$

where $\gamma$ denotes the risk aversion parameter, $\beta$ is the subjective discount factor, and $1-\nu$ is the probability of survival (described in more detail later in this section).

Technology Entrepreneurs produce a differentiated intermediate good by operating a constant returns to scale production technology $y=z k^{\alpha} n^{1-\alpha}$, where $z$ denotes their idiosyncratic productivity level, $k$ is the capital stock, and $n$ is the amount of labor hired. I assume that idiosyncratic productivity $z$ is distributed $\log$-normal with mean $\mu_{z}$ and standard deviation $\sigma_{z}$, and is fixed over their lifetime. 
Labor is hired on a period-by-period basis from competitive labor markets, while capital is accumulated internally by investing in final goods. Investment $x$ takes a period to be transformed into capital, and capital depreciates at rate $\delta$.

A firm that did not previously export has to pay a sunk export entry cost $S$ to be able to sell internationally. This cost is paid in units of final goods, and must be paid one period before the firm can export. Furthermore, exporters face an ad-valorem (iceberg) trade cost $\tau$.

Financial markets Entrepreneurs have access to domestic financial markets, where they can borrow or save in a one period risk-free bond denominated in units of the final good at an interest rate $r$. Entrepreneurs are assumed to face a collateral constraint, which limits the amount that they can borrow to a fraction $\theta$ of their capital stock. Thus, they can borrow an amount $d^{\prime}$ subject to $d^{\prime} \leq \theta k^{\prime}$ and the natural borrowing limit.

Entrepreneurs also have access to perfect annuity markets to insure themselves against the event of death. Every period, after the borrowing/saving and capital accumulation decisions are made, entrepreneurs sign a contract with a set of competitive insurance companies. Upon death, the agents' savings and capital are seized by the insurance company. Upon survival, the agent receives a payment $\frac{1}{1-\nu}$ proportional to their savings and capital position. Given that entrepreneurs have no bequest motive, they always choose to sign these contracts.

Entry and exit At the end of every period, entrepreneurs die with probability $\nu$. The capital stock and savings of dead entrepreneurs is transferred to surviving entrepreneurs via perfect annuity markets. A measure $\nu$ of entrepreneurs is also born at the end of every period, with an initial endowment of capital $\underline{k}$ financed via a lump-sum tax $T$ levied on all entrepreneurs, an idiosyncratic productivity level $z$ drawn from the stationary productivity distribution, and zero debt.

Market structure Entrepreneurs compete with each other under monopolistic competition, and choose how much to sell in each market and at what prices, subject to the quantity demanded by the final good producer in each of the markets. Denote quantities and prices corresponding to domestic sales by $y_{D}$ and $p_{D}$, and those corresponding to exports by $y_{X}$ and $p_{X}$, respectively. The demand functions faced in each of the markets are the solution to the final good producer's problem, as described above. 
Entrepreneurs' dynamic programming problem Given this setup, the entrepreneurs' problem can be represented as the solution to the following dynamic programming problem:

$$
\begin{aligned}
& v(k, d, e, z)= \max \frac{c^{1-\gamma}}{1-\gamma}+\beta(1-\nu) v\left(k^{\prime}, d^{\prime}, e^{\prime}, z\right) \\
& \text { subject to } \\
& p c+p x+p d \frac{1+r}{1-\nu}+w n+e^{\prime}(1-e) p S=w+p_{D} y_{D}+p_{X} y_{X}+p d^{\prime}-T \\
& k^{\prime}=\frac{1}{1-\nu}[(1-\delta) k+x] \\
& d^{\prime} \leq \theta k^{\prime} \\
& y_{D}+\tau y_{X}=z k^{\alpha} n^{1-\alpha} \\
& y_{D}=\left(\frac{p_{D}}{p}\right)^{-\sigma} y \\
& y_{X}=\left(\frac{p_{X}}{\bar{p}^{*}}\right)^{-\sigma} \bar{y}^{*}
\end{aligned}
$$

where (1) is the budget constraint; (2) is the law of motion of capital; (3) is the collateral constraint; (4) is the production function; and (5) and (6) are the demand functions that solve the final good producers' problem described above.

Definitions Before proceeding, I introduce a few definitions to simplify the notation from here onwards. Let $\mathcal{S}:=\mathcal{K} \times \mathcal{D} \times \mathcal{E} \times \mathcal{Z}$ denote the state space of entrepreneurs, where $\mathcal{K}, \mathcal{D}, \mathcal{E}$, and $\mathcal{Z}$ denote the set of possible values of capital, debt, export status, and productivity, respectively. Finally, let $s \in \mathcal{S}$ denote an element of the state space.

\subsection{Rest of the world}

In goods markets, the rest of the world demands intermediates from domestic entrepreneurs, and supplies intermediates to domestic final good producers. The demand for intermediates produced by domestic entrepreneurs is assumed to be given by a downward-sloping demand function with constant elasticity of substitution:

$$
y_{X}=\left(\frac{p_{X}}{\bar{p}^{*}}\right)^{-\sigma} \bar{y}^{*}
$$


where $\sigma$ is the elasticity of substitution across varieties, and $\bar{y}^{*}$ and $\bar{p}^{*}$ are parameters denoting the aggregate quantity and price indexes of the rest of the world. The supply of intermediates from the rest of the world, which domestic final good producers import, is assumed to be perfectly elastic at price $\bar{p}_{M}$, which is set to be the numeraire good.

I assume that the economy cannot borrow or lend to the rest of the world and, thus, operates in an environment of international financial autarky. Thus, the interest $r$ is determined endogenously to equate the entrepreneurs' demand and supply of credit $d^{\prime}$.

\subsection{Equilibrium}

I now define an equilibrium of this economy. A stationary competitive equilibrium of this economy consists of:

- Prices $\{r, w, p\}$

- Policy functions $\left\{d^{\prime}, k^{\prime}, e^{\prime}, c, n, y_{D}, y_{X}, p_{D}, p_{X}, y, y_{M}\right\}$

- Value functions $v$

- Measure $\phi$

such that

1. Policy functions and value functions solve the entrepreneur's problem

2. Policy functions solve the final good producer's problem

3. Labor market clears

$$
\int_{\mathcal{S}} n(s) \phi(s) d s=1
$$

4. Domestic intermediate good market clears

$$
y_{D}(i)=y_{D}(s) \text { if } s_{i}=s
$$


5. Final good market clears

$$
\int_{\mathcal{S}}\left\{c(s)+x(s)+S e^{\prime}(s)[1-e(s)]\right\} \phi(s) d s=y
$$

6. Financial market clears

$$
\int_{\mathcal{S}} d^{\prime}(s) \phi(s) d s=0
$$

7. Measure $\phi$ is stationary

\subsection{Reformulation of the entrepreneur's problem}

I now reformulate the entrepreneur's problem to eliminate one endogenous state variable. This reformulation simplifies the subsequent analysis of the model, as well as its numerical solution. I then adjust and restate the equilibrium conditions that are affected by this reformulation.

The idea is that the net worth of entrepreneurs is a sufficient statistic to capture their wealth and borrowing capacity. Intuitively speaking, on the one hand, entrepreneurs with low capital relative to debt - that is, with low net worth - have low wealth and borrowing capacity, given the nature of the financial constraint. On the other hand, entrepreneurs with high capital relative to debt have high net worth and, thus, are both wealthier and have a higher borrowing capacity.

Formally, let $a:=k(1-\nu)-d$, where $a$ denotes the net worth of entrepreneurs adjusted by their survival probability. Then, the entrepreneur's problem is equivalent to the following problem:

$$
v(a, e, z)=\max _{e^{\prime}}\{\widetilde{v}(a, e, 0, z), \widetilde{v}(a, e, 1, z)\}
$$

where

$$
\begin{aligned}
\widetilde{v}\left(a, e, e^{\prime}, z\right)= & \max _{c, a^{\prime}} \frac{c^{1-\gamma}}{1-\gamma}+\beta(1-\nu) v\left(a^{\prime}, e^{\prime}, z\right), \\
& \text { subject to } \\
& p c+p a^{\prime}+p S e^{\prime}(1-e)=w+\pi(a, e, z)+\frac{1+r}{1-\nu} p a-T,
\end{aligned}
$$


where $a^{\prime}$ is also subject to the natural borrowing limit, and

$$
\begin{aligned}
\pi(a, e, z)= & \max _{p_{D}, y_{D}, p_{X}, y_{X}, n, k} p_{D} y_{D}+e p_{X} y_{X}-w n-(r+\delta) p k \\
& \text { subject to } \\
& y_{D}+\tau y_{X}=z k^{\alpha} n^{1-\alpha} \\
& k \leq \frac{a}{1-\nu-\theta} \\
& y_{D}=\left(\frac{p_{D}}{p}\right)^{-\sigma} y \\
& y_{X}=\left(\frac{p_{X}}{\bar{p}^{*}}\right)^{-\sigma} \bar{y}^{*}
\end{aligned}
$$

where $v(a, e, z)$ denotes the lifetime expected utility from starting the period with total net worth $a$, export status $e$, and productivity level $z$. The value function $\widetilde{v}\left(a, e, e^{\prime}, z\right)$ denotes the value $v(a, e, z)$, conditional on choosing next period's export status $e^{\prime}$. Finally, $\pi(a, e, z)$ denotes the total profits obtained by the entrepreneur from operating the firm at each point of the state space.

Now, with a slight abuse of notation, redefine the state space of entrepreneurs $\mathcal{S}:=\mathcal{A} \times \mathcal{E} \times \mathcal{Z}$, where $\mathcal{A}$ denotes the set of possible values of net worth.

Financial market clearing The only equilibrium condition affected by this reformulation, besides the entrepreneur's problem, is the clearing of financial markets. In the environment with international financial autarky, this condition becomes:

$$
\int_{\mathcal{S}} k(s)(1-\nu) \phi(s) d s=\int_{\mathcal{S}} a(s) \phi(s) d s
$$

\section{Mechanism}

In this section, I study the mechanism through which financial frictions distort allocations in the model. I first examine the role of financial frictions in distorting the decisions of firms, with particular emphasis on their export entry decisions. Then, I study the implications of these distortions for aggregate trade flows and output. 


\subsection{Financial frictions and firm decisions}

Financial frictions distort firms' decisions along several margins. I describe each of these margins in turn, and then proceed to illustrate how these shape their life-cycle dynamics.

Export entry decision Whether or not entrepreneurs are subject to financial constraints, their decision to start exporting is given by the following condition:

Pay sunk export entry cost $\Longleftrightarrow \widetilde{v}(a, 0,1, z) \geq \widetilde{v}(a, 0,0, z)$

That is, as long as the lifetime expected utility from starting to export is at least as high as that from remaining a non-exporter, the entrepreneur chooses to pay the sunk export entry cost.

Financial frictions affect firms' export entry decisions by distorting the value of $\widetilde{v}(a, 0,1, z)$ relative to $\widetilde{v}(a, 0,0, z)$ at different levels of net worth and productivity. Financial frictions lower the value of exporting through two channels. First, they reduce the entrepreneurs' potential to smooth out the payment of sunk costs across their lifetime and, thus, are forced to rely relatively more on internal funds, which leads to a larger drop in consumption upon entry. Second, financial frictions reduce the returns to exporting, by reducing the firms' scale of operation upon entry to foreign markets. Figure 1 illustrates how financial constraints distort firms' export entry decisions by comparing the export entry policy function between the model with and without financial constraints.

The top panel plots the export entry policy function for the model without financial constraints. As in standard models of international trade with firms heterogeneous in productivity, there is a threshold level of productivity such that firms above it choose to export (that is, $e^{\prime}=1$ ), while those below it choose not to. The reason is simple: Firms' profits in the foreign market are increasing in $z$, while the cost of entry to this market is independent of productivity. Thus, when productivity is sufficiently low, lifetime expected profits from starting to export are lower than the sunk export entry cost, and these firms do not export.

The bottom panel plots the export entry policy function for the model with financial constraints. As in the frictionless model, and for the same reasons, there is a threshold level of productivity such that only firms above it choose to export. In addition, productive firms with sufficiently low net worth do not export - only those above a minimum level of net worth choose to do so. As discussed earlier, 

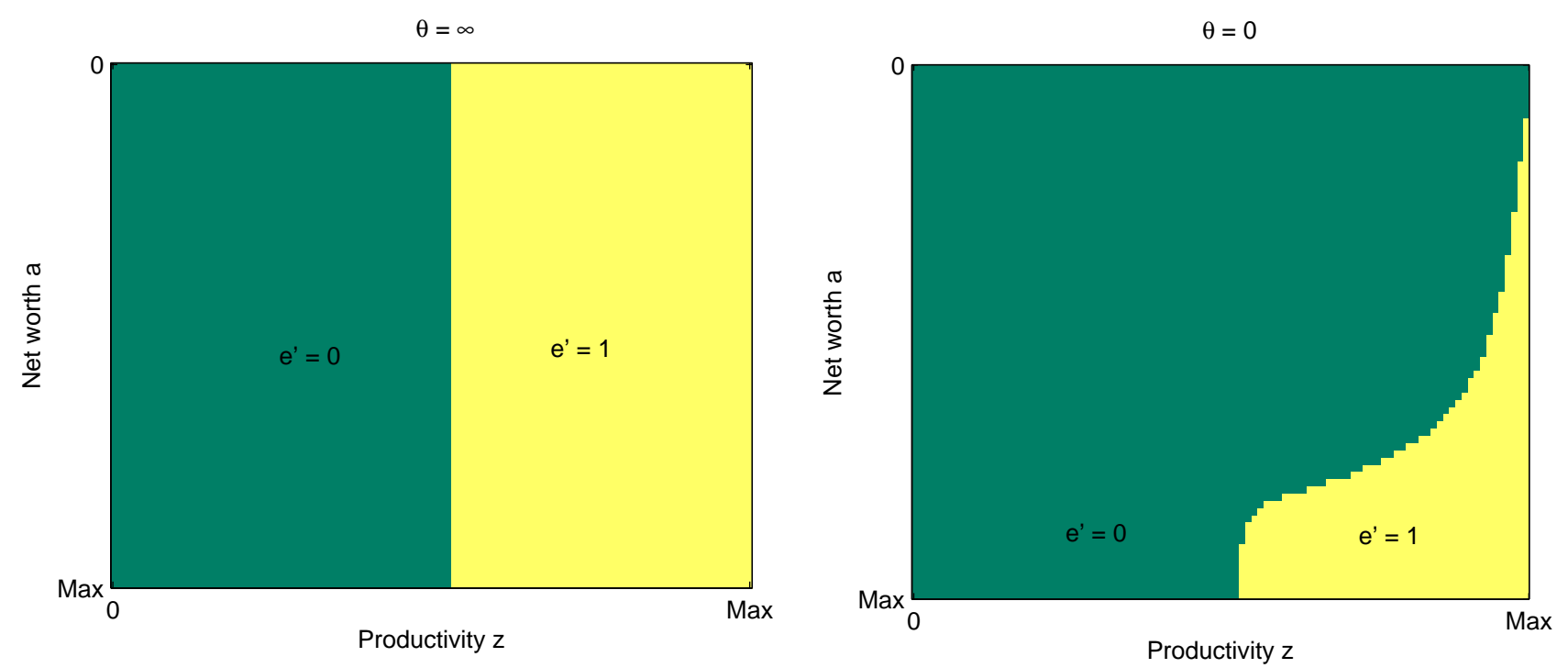

Figure 1: Export entry policy functions and financial frictions

with financial constraints, firms with low net worth either cannot afford to finance the sunk export entry cost, or they do not find it profitable to start exporting. Given the constrained scale at which they would export, and the drop in internal funds and consumption required to pay for the entry cost, only firms with high enough net worth choose to export. Note that the minimum level of net worth at which these firms start exporting is decreasing in productivity: Firms with higher productivity make relatively higher profits, per unit of net worth, from exporting, thus finding it more profitable to pay the sunk cost, conditional on being able to afford it.

Production decisions Whether or not firms export, their production decisions are determined by the simple static problem presented at the end of the previous section - with $\pi(a, e, z)$ denoting the total profits associated with the solution to this problem.

Financial frictions distort entrepreneur's production decisions by reducing the scale at which they can choose to operate the firm. If $\theta<1-\nu$, the entrepreneur can operate the firm with a capital stock that is, at most, as high as $\frac{a}{1-\nu-\theta}$. In contrast, as long as $\theta \geq 1-\nu$, the firm can operate with a capital stock that is as high as desired. Thus, the net worth of the entrepreneur determines the production possibility frontier for each entrepreneur. From the lens of the original formulation of the model, this is sensible - with $\theta \geq 1-\nu$, agents can fully collateralize the amount borrowed, as long as it is used to purchase an increase in the capital stock. Therefore, in this case, they have access to any desired 


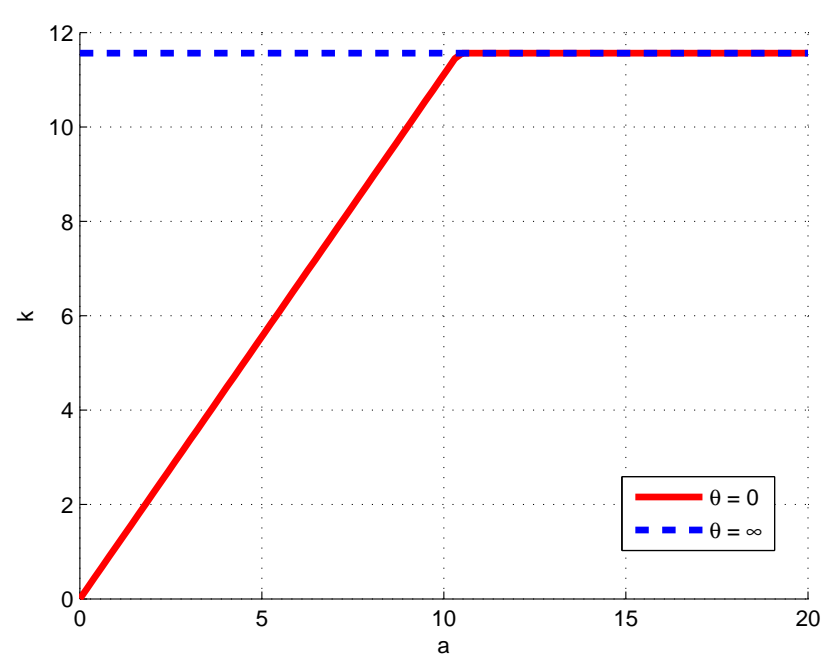

Figure 2: Capital $k$ policy function, conditional on $e$ and $z$

amount of funds as long as it leads to a more than equivalent increase in the size of the collateral.

However, the extent to which financial constraints distort firms' production decisions depends on the interaction between their production possibility frontier and their desired scale of operation. The entrepreneur's export status $e$ and productivity level $z$ determine the scale that maximizes profits, conditional on prices and aggregate quantities. As in standard models, participation in international trade, and higher productivity lead to a higher desired optimal scale. Therefore, given $a$, productive firms are relatively more distorted - that is, their scale of production relative to their frictionless scale is lower than for less productive firms.

Figure 2 illustrates the optimal policy for the amount of capital at which the firm operates as a function of its level of net worth. In the model with financial frictions, the level of capital is increasing in net worth until the firm accumulates sufficient net worth to allow it to produce at its optimal scale. In contrast, in the model without financial frictions, the level of capital owned by the firm is independent of net worth, and always at its optimal level.

Financial frictions distort not only the optimal scale at which entrepreneurs operate, but also the optimal mix of inputs used for production - that is, the optimal ratio of capital to labor. In particular, the capital-labor ratio is given by:

$$
\frac{k}{n}=\frac{\alpha}{1-\alpha} \frac{w / p}{\left(r+\delta+\mu_{\theta}\right)},
$$




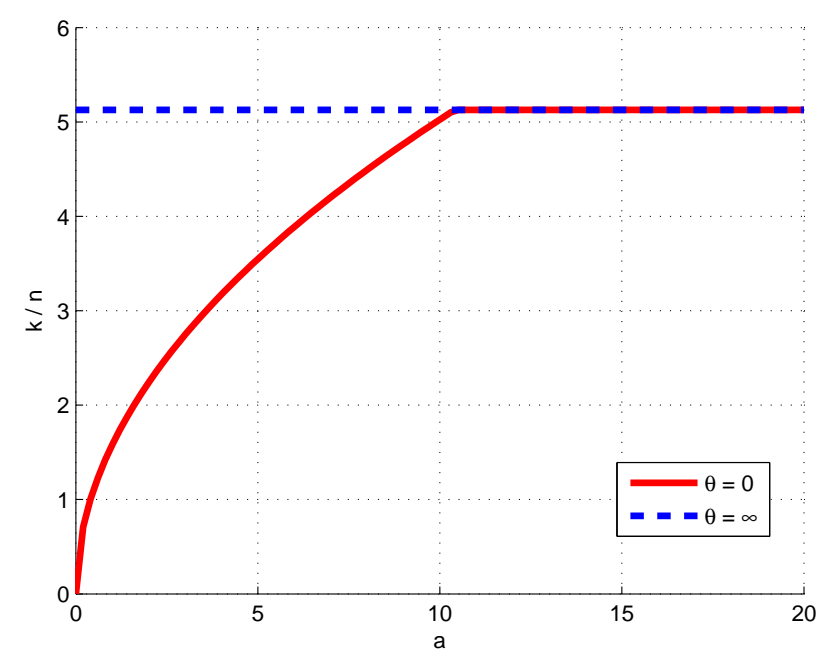

Figure 3: Capital $k$ to labor $n$ ratio, conditional on $e$ and $z$

where $\mu_{\theta}$ is the Lagrange multiplier on the collateral constraint. As long as the firm is financially constrained, we have that $\mu_{\theta}>0$, thus lowering the ratio of capital to labor at which entrepreneurs operate. To the extent that they are unconstrained, all entrepreneurs operate at the same capital-labor ratio.

While this distortion does not affect the entrepreneur's level of output, it does affect his profit level and translates into a distortion to the level of aggregate productivity at which the economy operates, as described later in this section. Figure 3 illustrates the capital-labor ratio as a function of its level of net worth. In the frictionless model, firms can always operate at their optimal $k / n$ ratio, which, in particular, is independent of net worth. In contrast, in the model with financial frictions, the $k / n$ ratio is an increasing function of net worth. At low levels of $a$, the firm operates with a sub-optimal level of capital, thus hiring relatively more labor. As $a$ increases, the firm can hire increasingly more capital, thus increasing its $k / n$ ratio until it is able to operate using the optimal mix of inputs.

Net worth dynamics As derived in the previous section, the entrepreneur cares about the dynamics of capital $k$ and debt $d$ only to the extent that they affect his total net worth $a=k(1-\nu)-d$. Therefore, throughout the rest of the paper, I focus on the evolution of net worth, rather than on the dynamics of capital and debt separately.

As long as the entrepreneur does not choose to switch export status in the current period (that is, to start exporting, when he currently does not), the dynamics of net worth in the model are determined 
by the following Euler equation:

$$
\beta c^{\prime-\gamma}\left[1+r+\frac{(1-\nu) \mu_{\theta}^{\prime}}{1-\nu-\theta}\right]=c^{-\gamma}
$$

where $\mu_{\theta}$ denotes the Lagrange multiplier on the borrowing constraint.

In the model without financial constraints, $\mu_{\theta}=0$ for all entrepreneurs. Therefore, entrepreneurs increase or decrease their net worth to equate the current period's return to consuming a unit of wealth, $c^{-\gamma}$, with the return to saving it to the following period. The latter is higher to the extent that the discount factor and interest rate are higher, as is standard.

In contrast, in the model with financial constraints, $\mu_{\theta}>0$ for some entrepreneurs. In this case, the next period's return to an additional unit of future net worth is, in addition, determined by the marginal increase in profits obtained from operating the firm with an additional unit of net worth - that is, by the magnitude of the Lagrange multiplier $\mu_{\theta}$. As long as the borrowing constraint is binding, an additional unit of net worth allows entrepreneurs to operate their production technology at a higher scale: that is, to borrow relatively more to finance the purchase of a higher capital stock.

If the entrepreneur chooses to start exporting in the current period, the dynamics of net worth are not determined by the Euler equation. Given the discrete impact of the firm's export entry decision on its net worth, the entrepreneur is not able to equate the current and future marginal returns to an extra unit of net worth - instead, he chooses the level of net worth that maximizes future expected lifetime utility, whether by starting to export or not.

Figure 4 illustrates how financial constraints distort entrepreneurs' net worth accumulation decision before entry to the export market. I restrict attention to a firm with high enough productivity $z$, such that it chooses to export with sufficiently high net worth. In the model with financial frictions, entrepreneurs increase their net worth at high rates when its level is low - to increase their production scale as well as to increase the internal funds available to pay the sunk export entry cost. For sufficiently high levels of net worth, firms pay the sunk export entry cost, which leads to a decrease in their net worth level. In contrast, in the frictionless model, firms pay the sunk export entry cost at all levels of net worth, thereby reducing its level. ${ }^{10}$

Similarly, Figure 5 illustrates how financial constraints distort entrepreneurs' net worth accumula-

\footnotetext{
${ }^{10}$ While, in the frictionless model, entrepreneurs can hold negative levels of net worth, I restrict attention to the region of the state space in which this is positive to ease the comparison with the financial frictions model.
} 


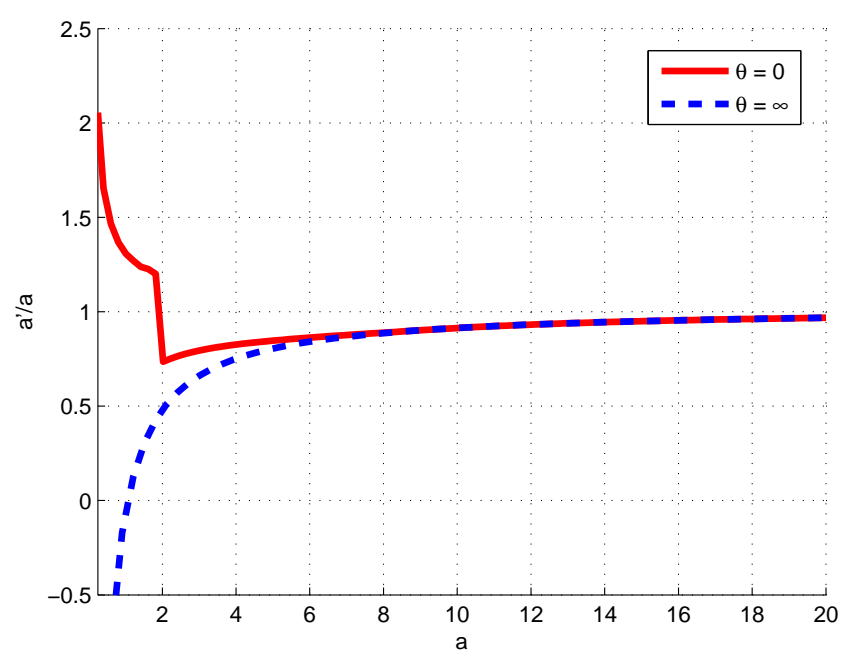

Figure 4: Net worth accumulation policy functions, conditional on $e=0$ and $z$

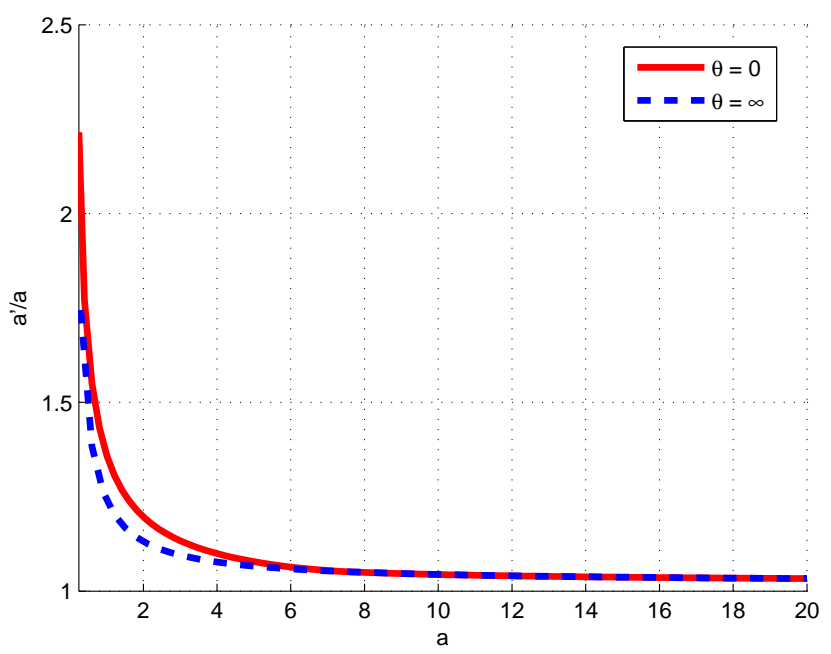

Figure 5: Net worth accumulation policy functions, conditional on $e=1$ and $z$

tion decision after entry to the export market. The key difference from the previous policies is that they reflect the net worth dynamics conditional on having paid the sunk export entry cost. In the frictionless model, firms increase their net worth as they pay back their debt and take advantage of the market interest rate. In the model with financial frictions, firms have an additional motive to increase their net worth: to increase their production scale, until reaching their optimal level. Thus, firms increase their net worth at a faster rate when their scale is low and their financial constraint binds, and at the same rate as firms in the frictionless model once they reach their optimal scale. 


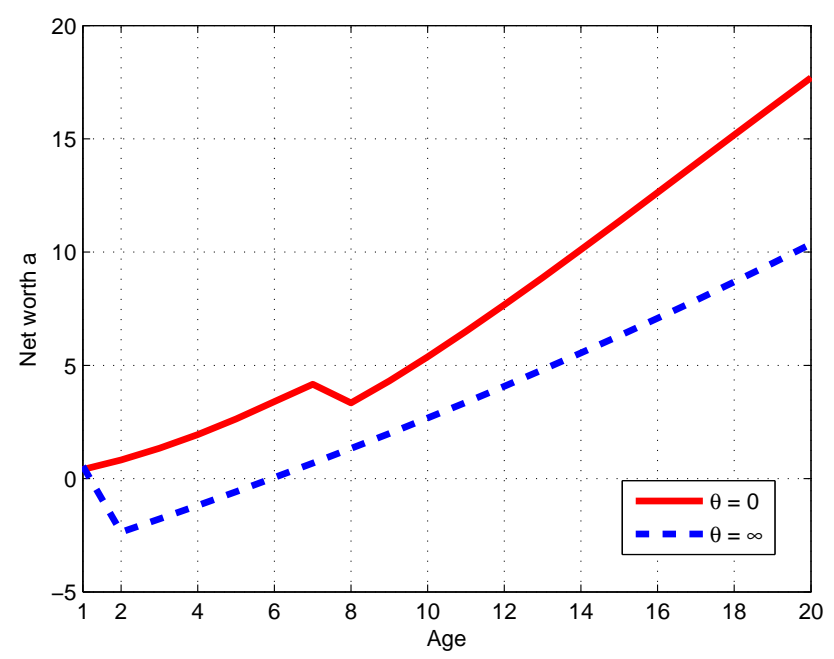

Figure 6: Average net worth, conditional on $z$

Life-cycle dynamics While the discussion, so far, has focused on the different channels through which financial frictions distort firms' decisions, these channels do not necessarily give a clear sense of what the dynamics of a typical firm in the model look like. That is the focus of this subsection.

Recall that firms in the model are born with a low level of net worth, and die at a stochastic age-independent probability rate $\nu$. It is, therefore, instructive to examine the dynamics of firms in the model by considering the life-cycle dynamics of firms belonging to a sample cohort. Figure 6 plots the net worth dynamics corresponding to a cohort of new firms (with productivity such that they export), and contrasts them with those in the economy without financial frictions.

In the model with financial frictions, new firms accumulate internal funds over their first few years of life in order to increase their scale of operation and to save enough to pay the sunk export entry cost. At some point, after a few years, with sufficiently high internal funds, the firms pay the sunk export entry cost ${ }^{11}$ partially running down their internal funds. In contrast, in the model without financial frictions, the cohort of new firms runs down its internal funds and borrows in order to pay the sunk export entry cost; thus, their net worth decreases between the ages of one and two. From age two onwards, firms increase their net worth. ${ }^{12}$

\footnotetext{
${ }^{11}$ Recall that I restrict attention to a cohort of firms with a sufficiently high level of productivity such that they find it optimal to export with high enough net worth.

${ }^{12}$ Note that, given that firms die with probability $\nu$ every period, the aggregate level of net worth does not increase indefinitely.
} 


\subsection{Financial frictions and international trade}

I now examine the channels through which the distortions of firms' decisions due to financial constraints affect the ratio of exports to GDP at the aggregate level. To do so, I find it convenient to decompose the channels that determine the ratio of exports to domestic sales $X / D$, which features a monotonic relationship with the ratio of exports to $\mathrm{GDP}^{13}$. In particular, a higher ratio of exports to domestic sales implies a higher ratio of exports to GDP. At this point, this decomposition helps to illustrate the different channels through which financial development affects the relative level of international trade. In the next section, I use this decomposition to disentangle the forces driving the quantitative results.

The ratio of aggregate exports to domestic sales in the model can be expressed as:

$$
\frac{X}{D}=\underbrace{\frac{\frac{1}{S_{x}} \int_{\mathcal{E}}\left[z\left(\frac{r+\delta}{r+\delta+\mu_{\theta}(s)}\right)^{\alpha}\right]^{\sigma-1} \phi(s) d s}{\int_{\mathcal{S}}\left[z\left(\frac{r+\delta}{r+\delta+\mu_{\theta}(s)}\right)^{\alpha}\right]^{\sigma-1} \phi(s) d s}}_{\text {Relative size of exporters }} \times \underbrace{S_{x}}_{\text {Share of exporters }} \times \underbrace{\frac{\bar{y}^{*} \overline{p^{*} \sigma}}{y p^{\sigma}} \tau^{1-\sigma}}_{\text {Exporter-level } X / D}
$$

where $\mu_{\theta}$ is the Lagrange multiplier on the entrepreneurs' borrowing constraint, and $S_{x}$ denotes the share of firms that export ${ }^{14}$. This expression shows that the ratio of aggregate exports to domestic sales is given by the product of three terms: $(i)$ relative scale of exporters; $(i i)$ share of exporters; and (iii) exporter-level $X / D$.

The first term, the relative size of exporters, measures the average scale of firms that sell internationally, relative to all the firms in the economy. To the extent that firms that trade internationally are more productive than those operating domestically, they end up charging lower prices and, thus, selling relatively more (in terms of quantity and revenue) than domestic firms. In addition to productivity, firm size is determined by the extent to which financial constraints bind. That is, $\mu_{\theta}>0$ for constrained firms, and so $\frac{r+\delta}{r+\delta+\mu_{\theta}(s)}<1$, reducing the weight assigned to constrained firms. Thus, the effect of financial development on the relative size of exporters depends on the change in exporters' average level of technological productivity, as well as on the extent to which exporters become relatively more (or less) unconstrained than non-exporters.

The second term, the share of exporters, measures the number of firms that sell internationally relative to those operating domestically (which is normalized to 1): The larger the number of firms

\footnotetext{
${ }^{13}$ Specifically, note that $\frac{X}{G D P}=\frac{1}{1+D / X}$.

${ }^{14}$ Formally, $S_{x}:=\int_{\mathcal{E}} \phi(s) d s$.
} 
operating internationally, the larger the ratio of exports to domestic sales at the aggregate level. The previous subsection discussed the potential of financial constraints to distort firms' export entry decisions. To the extent that firms choose not to export because of the difficulty of financing the sunk export entry cost, a relaxation of the financial constraint can lead to an increase in the share of exporters and, thus, to an increase in the aggregate ratio of exports to total sales.

The last term denotes the exporters' ratio of exports to domestic sales. Conditional on exporting, all firms feature the same $X / D$ ratio (that is, $p_{X} y_{X} / p_{D} y_{D}$ ), regardless of the extent to which financial constraints bind or not. The optimal ratio of exports to domestic sales at the firm-level is determined by the size of the foreign market relative to the domestic market, adjusted by the size of international trade costs and the degree of competition. When foreign demand is relatively larger than domestic demand, firms engaged in international trade find it profitable to sell a higher fraction of their total sales abroad. Given that $\bar{y}^{*} \bar{p}^{*}$ is fixed exogenously, financial development leads to an increase in aggregate output, implying a decrease in firm-level $X / D$ and, thus, to a decrease in the ratio of exports to domestic sales at the aggregate level.

The overall impact of financial development on the ratio of exports to domestic sales depends on its relative impact on each of these terms. Financial development can be expected to lead to a decrease in the exporters' $X / D$ and to an increase in the share of exporters; however, its effect on the relative productivity of exporters is ambiguous and depends on the relative change of their average productivity and on the extent to which they become relatively more unconstrained than non-exporters. I explore the relative importance of each of these terms quantitatively in the next section.

\subsection{Financial frictions, international trade, and aggregate output}

Regardless of their impact on the relative level of international trade, financial frictions affect the level of output at the aggregate level. In this subsection, I decompose the channels through which they do so. In the next section, I use this decomposition to analyze the sources driving the quantitative results. 
Total production of the final good can be expressed as the following aggregate production function: ${ }^{15}$

$$
y=\operatorname{TFP} N^{1-\alpha} K^{\alpha}
$$

where

$\mathrm{TFP}:=\underbrace{\left[\int_{\mathcal{S}}\left[1+e(s) \tau^{1-\sigma} \frac{y^{*}}{y}\left(\frac{p^{*}}{p}\right)^{\sigma}\right]\left[z\left(\frac{r+\delta}{r+\delta+\mu_{\theta}(s)}\right)^{\alpha}\right]^{\sigma-1} \phi(s) d s\right]^{\frac{1}{\sigma-1}}}_{\text {Scale distortions }} \underbrace{\left[\frac{N}{\int_{\mathcal{S}} n(s) \frac{r+\delta}{r+\delta+\mu_{\theta}(s)} \phi(s) d s}\right]^{\alpha}}_{\mathrm{K} / \mathrm{L} \text { distortions }}$,

where $\mathrm{N}:=\int_{\mathcal{S}} n(s) \phi(s) d s$ and $\mathrm{K}:=\int_{\mathcal{S}} k(s) \phi(s) d s$. In other words, the total amount of the final good produced in the economy can be expressed as function of the aggregate stock of capital and labor, weighted by their respective shares in the entrepreneurs' production technology, multiplied by the endogenous level of aggregate total factor productivity (TFP) in the economy.

The level of aggregate TFP is a function of two terms. The first term captures what I refer to as "scale distortions" — that is, the contribution to aggregate productivity of distortions to the optimal scale of firms given that they cannot accumulate capital and access export markets fast enough. To the extent that some firms do not export when it would have been optimal for them to do so $(e=0$ instead of $e=1$ ), or that some firms have a binding borrowing constraint $\left(\mu_{\theta}>0\right)$, the first term is relatively lower than in an economy without financial frictions. Note that the degree to which distortions to international trade affect the level of aggregate output depends crucially on the exporters' $X / D$ ratio, as described above. Insofar as the effective demand in foreign markets is relatively larger than that faced in the domestic market, distortions of firms' export entry decisions can have a large impact on the level of the economy's aggregate productivity.

The second term is referred to as "K/L distortions", since it captures the aggregate effect of financial frictions' distortions on the optimal ratio of capital to labor used in production. As discussed above, when the financial constraint binds, firms operate with a sub-optimal level of capital and, thus, end up hiring more labor relative to capital than is efficient. Therefore, the marginal productivity of capital is relatively higher than in an economy without financial frictions. This higher marginal productivity of capital is captured by the "K/L distortions" term, and leads to a higher level of aggregate TFP than

\footnotetext{
${ }^{15}$ This expression is valid for the environment with international financial autarky, in which trade is balanced (that is, net exports are equal to zero). A similar expression can be derived for the environment with international financial integration.
} 
in a frictionless economy.

While, on the one hand, financial development is likely to lead to an increase in the "scale distortions" term, on the other hand, it leads to a decrease in the "K/L distortions." Therefore, the overall direction of the impact of financial development on aggregate TFP and its magnitude are, in principle, a quantitative matter. In the next section, I quantify the extent to which financial development leads to an increase in aggregate TFP.

Finally, note that the previous expression for aggregate TFP can be rewritten such that the role of distortions in international trade is made more transparent. In particular, an equivalent expression for aggregate TFP for the environment with international financial autarky is the following:

$$
\mathrm{TFP}=\left[1-\frac{\mathrm{X}}{\mathrm{GDP}}\right]^{\frac{1}{1-\sigma}}\left[\int_{\mathcal{S}}\left[z\left(\frac{r+\delta}{r+\delta+\mu_{\theta}(s)}\right)^{\alpha}\right]^{\sigma-1} \phi(s) d s\right]^{\frac{1}{\sigma-1}}\left[\frac{N}{\int_{\mathcal{S}} n(s) \frac{r+\delta}{r+\delta+\mu_{\theta}(s)} \phi(s) d s}\right]^{\alpha}
$$

As in standard models of international trade, distortions to the relative level of international trade namely, the ratio of aggregate exports to GDP — play a key role in affecting the level of aggregate TFP. In this model, however, they can also affect the level of aggregate TFP by distorting the effective level of productivity of the economy - the second term of the above expression. Specifically, $\mu_{\theta}>0$ to the extent that firms engaged in international trade operate at a suboptimal scale, and, thus, the contribution of these firms to the aggregate level of productivity is relatively lower. Given that firms engaged in international trade are likely to be the most productive ones, this effect can, in principle, have a large impact on aggregate TFP, beyond the standard channel.

\section{Quantitative analysis}

In this section, I study the quantitative implications of the model. I begin by calibrating the model to match key moments from Chilean firm-level data. I then use the calibrated model to examine the extent to which it can account for the relationship between financial development and international trade observed in the data. Finally, I examine the implications of financial development for aggregate output. 


\subsection{Calibration}

In this subsection, I discuss the approach followed to calibrate the model. The parameter space is partitioned into two. The first group of parameters is set to standard values from the literature. The second group of parameters is calibrated to match key moments from the data.

The group of pre-assigned parameters consists of the preference parameters $\gamma, \sigma$, and $\beta$, and the technological parameters $\alpha$ and $\delta$. Risk aversion $\gamma$ is set to 2 , the discount factor $\beta$ to 0.96 , and the elasticity of substitution across varieties $\sigma$ to 4 . The capital share $\alpha$ in production is set to 0.33 , and the rate of capital depreciation $\delta$ to 0.06 . These values fall well within the range of values that have been used in previous studies.

The group of calibrated parameters consists of $S, \nu, \tau, \sigma_{z}$, the initial level of net worth $a_{\text {new }}$, and $\theta$. I choose them to match the following moments for Chilean manufactures: (1) share of exporters; (2) death rate; (3) ratio of total exports to total sales; (4) exporter size premium (ratio of average foreign sales to average domestic sales); (5) average sales at age five relative to the average sales upon birth among new firms that survive for at least five years; and (6) ratio of total credit to total value added. The target moments (1) - (6) are computed using Chilean firm-level data from the Chilean Annual Manufacturing Survey (ENIA), collected by the Chilean National Institute of Statistics (INE) for the years 1995 to $2007 .{ }^{16}$ For (6), I use the value of total credit to the manufacturing sector from Superintendencia de Bancos e Instituciones Financieras de Chile, and value added from Chilean firm-level data.

While all parameters affect each of these moments, I now provide a heuristic argument for thinking about the mapping between the calibrated parameters and the targeted moments. The dispersion of idiosyncratic productivity $\sigma_{z}$ is informative about the exporter size premium, by affecting the dispersion between high- and low-productivity firms and, hence, exporters and non-exporters. The sunk export entry cost $S$ allows me to identify the share of firms that choose to export, by affecting the export entry threshold described in the previous section. The collateral constraint parameter $\theta$ affects the amount of credit taken in the economy, as reflected by the aggregate ratio of credit to value

\footnotetext{
${ }^{16}$ The survey collects longitudinal data on all plants with more than ten workers. I exclude observations with negative or missing sales in the domestic or foreign markets, as well as those with zero or missing total sales. I also exclude observations from the following International Standard Industrial Classification (ISIC) Revision 3 categories, given their large dependence on natural resource extraction and large price fluctuations: category 2720 (manufactures of basic precious and non-ferrous metals); and category 2411 (manufactures of basic chemicals except for fertilizers and nitrogen compounds). Our empirical results are robust to the inclusion of these categories.
} 
added - with higher values of $\theta$, firms choose to borrow relatively more. The level of endowment of net worth of new firms $a_{\text {new }}$ is calibrated to target the ratio of average sales at age five to the average sales upon birth. The lower the initial level of net worth, the lower the initial scale of firms and, thus, the larger the growth of total sales that firms experience throughout their first years of life. The iceberg trade cost parameter $\tau$ is informative about the aggregate ratio of exports to total value added in the economy since it controls the extent to which sales abroad are costlier than domestic sales, conditional on exporting. The idea is that $\tau$ is chosen as a residual that accounts for the gap between the amount of international trade predicted by the other forces of the model (e.g., sunk export entry costs), and the amount of trade observed in the data. In this sense, while $\tau$ is a technological parameter in the context of the model, it should be interpreted more broadly as capturing all other forces and factors that may curb the amount of international trade in the economy. In particular, it may capture technological as well as demand/preference factors. Finally, the death rate $\nu$ is chosen to match the exit rate of firms.

The price of imported goods $p_{M}$ is set as numeraire, and the quantity $\bar{y}^{*}$ and price $\bar{p}^{*}$ of the final good in the rest of the world are normalized to 10 and 1 , respectively ${ }^{17}$ Finally, the average level of productivity $\mu_{z}$ is normalized to 1 .

The parameters used in the calibration are presented in Table 1, while the moments targeted and their model counterparts are presented in Table 2. The model is solved using an adaptation of the endogenous grid method ${ }^{18}$ to account for the discrete nature of the export entry decision, using the entrepreneurs' policy functions to compute the stationary distribution across their individual states via discretization. ${ }^{19}$

\subsection{Firm-level implications}

In this subsection, I examine the firm-level implications of the calibrated economy and compare them with their empirical counterparts from the Chilean firm-level data. The goal is to examine the performance of the model along dimensions of the data that have not been directly targeted in the calibration strategy, in order to put the counterfactual results of the following subsections into context. Given the

\footnotetext{
${ }^{17}$ In this model, the size of the rest of the world can be normalized, since all that matters for firm decisions is the product $\bar{y}^{*} \tau^{1-\sigma}$ - that is, the effective demand faced by exporters, after controlling for variable trade costs. To the extent that the size of the rest of the world is normalized to some value, our calibration of $\tau$ is adjusted such that the model predicts the target level of trade in the economy.

${ }^{18}$ Carroll (2006).

${ }^{19}$ Heer and Maussner (2005).
} 
Table 1: Parameter values

\begin{tabular}{lcc|lcc}
\hline \hline \multicolumn{1}{c|}{ Assigned parameters } & & \multicolumn{4}{c}{ Calibrated parameters } \\
& & & & \\
& & & & & \\
& & & & \\
Discount factor & $\gamma$ & 2 & Iceberg trade cost & & 3.81 \\
Risk aversion & & 4 & Peath rate & $\nu$ & 0.10 \\
Elasticity of substitution & $\sigma$ & Productivity dispersion & $\sigma_{z}$ & 0.2875 \\
Capital share & $\alpha$ & 0.33 & Sunk export entry cost & $S$ & 0.947 \\
Depreciation rate & $\delta$ & 0.06 & Collateral constraint & $\theta$ & 0.35 \\
& & & Initial net worth & $a_{\text {new }}$ & 0.24 \\
& & & & & \\
\hline \hline
\end{tabular}

stylized nature of the model, the goal is not necessarily to account exactly for all of these moments, but to understand the extent to which the model can capture them, either qualitatively or quantitatively. This can help to give a better sense of the force and nature of the mechanism that this paper evaluates. Panel B of Table 2 reports these additional moments.

I begin by examining the implications of the model for the amount of collateral that firms are required to post per unit of funds borrowed, and I contrast it with direct evidence from firm-level data. In the model, the amount of collateral that firms are required to post is equal to $1 / \theta^{20}$, which is equal to 2.90 in the model. I contrast this value with evidence from Chilean firm-level data from the World Bank Enterprise Survey, ${ }^{21}$, in which firms are asked to report the amount of collateral they post per unit borrowed, conditional on having a loan that requires collateral. In these data, the average amount of collateral that Chilean firms are required to post is 1.64 . Therefore, firms in the model face a tighter borrowing constraint than firms in the data. This suggests that the implications of the model may be interpreted as an upper bound on the tightness of the constraints faced by firms in Chile.

The model does a relatively good job of capturing the relative contribution of exporters to aggregate variables in the economy. For instance, the share of aggregate total sales that exporters account for is 57-percent in the model, while it is 65-percent in the data. Similarly, the share of aggregate domestic sales that exporters account for is 42-percent in the model, and 55-percent in the data. While relatively

\footnotetext{
${ }^{20}$ The interpretation is that, while firms may choose to operate with a lower leverage ratio $\left(d^{\prime} / k^{\prime}\right)$, the maximum amount of leverage at which they can borrow is $\theta$. Therefore, the minimum amount of collateral that they can post to get an additional unit of funds is $1 / \theta$.

${ }^{21}$ For a more detailed description of the data and methodology, see the documentation that is freely available from http://www.enterprisesurveys.org/methodology.
} 
Data Model

A. Used to calibrate model

$\begin{array}{rrr}\text { Share of firms that export } & 0.21 & 0.21 \\ \text { Exporter size premium } & 4.81 & 4.82 \\ \text { Death rate } & 0.10 & 0.10 \\ \text { Aggregate Exports / Sales } & 0.25 & 0.25 \\ \text { Aggregate Credit / Value added } & 0.50 & 0.50 \\ \text { Average total sales growth between ages 1 to } 5 & 1.53 & 1.65\end{array}$

\section{B. Additional moments}

Average collateral per $\$$ borrowed $\quad 1.64 \quad 2.90$

S.D. total sales $\quad 1.69 \quad 0.86$

S.D. domestic sales $1.62 \quad 0.69$

S.D. export sales $2.54 \quad 0.22$

Share of total sales by exporters $\quad 0.65 \quad 0.57$

Share of domestic sales by exporters $\quad 0.55 \quad 0.42$

Export participation, smallest third in domestic sales $\quad 0.09 \quad 0.00$

Export participation, middle third in domestic sales $\quad \begin{array}{lll}0.13 & 0.07\end{array}$

Export participation, largest third in domestic sales $\quad \begin{array}{lll}0.40 & 0.56\end{array}$

S.D. total sales growth $\quad 0.40 \quad 0.09$

Average K/L $\quad 1.18 \quad 1.98$

S.D. $\log (\mathrm{K} / \mathrm{L}) \quad 1.44 \quad 0.30$

Average K/L, exporters relative to non-exporters $2.22 \quad 1.00$

S.D. $\log (\mathrm{K} / \mathrm{L})$, exporters relative to non-exporters $\quad 0.91 \quad 0.78$

close to the data, the model underpredicts the contribution of exporters to economic aggregates. With regard to the response of aggregate exports relative to aggregate output in the economy, the current calibration of the model assigns less weight to the response of exporters relatively to that of nonexporters in accounting for their impact on aggregate output.

A key channel through which financial frictions distort aggregate trade flows in the model is by 
distorting firms' export entry decisions. Therefore, a key dimension of the data that one would want the model to capture is the extent to which different types of firms choose whether or not to export. I now focus on one particular dimension along which firms differ: total sales in the domestic market. ${ }^{22}$ To do so, I divide firms into three groups according to their size in the domestic market, such that one third of firms falls into each group. I do so in both the model and the data, and compute the share of firms in each group that exports. In the model, I find that most of the largest firms (56\%) participate in international trade while, in the data, 40-percent of these firms choose to do so. In contrast, only a small share of firms export in the two smallest groups - in the model, the shares are seven percent and zero percent, respectively, and in the data, these shares are 13-percent and nine percent respectively. While the model predicts that a larger share of big firms exports than observed in the data, ${ }^{23}$ both the model and the data sharply predict that this group is the one with the highest share of exporters. This suggests that the model can do reasonably well in accounting for an important dimension of the extensive margin of international trade.

The other key channel through which financial frictions distort aggregate trade flows in the model is by distorting production decisions along the intensive margin. These distortions not only lower the scale at which exporters operate, but also reduce the returns to paying the sunk export entry cost, as discussed in the previous section. In order to study the response of aggregate exports to total output, a key dimension of the data that one would want the model to capture is the extent to which the production decisions of firms that export are distorted relative to those that do not. As discussed earlier, distortions of firms' decisions along this margin map directly into distortions of firms' ratio of capital to labor ${ }^{24}$. Thus, I compare the dispersion of K/L between exporters and non-exporters. I find that both the model and the data imply that non-exporters feature relatively more dispersion in this ratio than exporters - in the model, this is the case exactly because non-exporters are typically younger and, thus, more financially constrained. While their magnitudes are similar, the model implies that exporters are relatively more unconstrained than non-exporters in the model than in the data the relative standard deviation of $\log K / L$ is 0.91 in the data, yet 0.78 in the model.

\footnotetext{
${ }^{22}$ I focus on their size in the domestic market rather than on their total size - larger firms in terms of total size will be more likely to be larger, simply because they operate in a larger number of markets.

${ }^{23}$ The fact that the model implies a lower share of small firms is a necessary implication of this fact, since both the model and the data have the same aggregate share of exporters.

${ }^{24}$ Recall that, to the extent that there are no financial frictions, the K/L ratio is identical across all firms - in contrast, the tighter the financial constraints, the higher the variation in this ratio.
} 


\subsection{Financial development and international trade}

The previous discussion suggests that, while very stylized, the model can account reasonably well for dimensions of the data that play a key role in the mechanism through which financial frictions distort allocations in the model, with particular emphasis on international trade. Thus, I now use the calibrated model as a laboratory to investigate the macroeconomic implications of financial development on international trade. Specifically, I study the effect of alternative values of $\theta$ on the ratio of aggregate exports to GDP. Panels A to C of Table 3 report these results. Each column reports the results implied by different parametrizations of the model. The first column corresponds to the baseline calibration to the Chilean economy, while the second and third correspond to the model with no credit $(\theta=0)$ and without frictions $(\theta=\infty)$, respectively.

Panel A reports the ratio of exports to GDP and the amount of credit across the different parametrizations of the model. As can be readily observed, changes in the financial frictions parameter $\theta$ from zero to $\infty$ lead to a large increase in the amount of credit relative to value added taken by entrepreneurs, from zero to 1.11. However, it leads to negligible changes in the size of aggregate exports relative to GDP - this ratio increases from 0.25 in the economy without credit, to 0.27 in the economy with credit. These results suggest that, in this model, differences in financial development cannot account for the relationship between financial development and the size of exports relative to output that is observed in the data.

I now study the forces that account for this result. I begin by decomposing the change in the ratio of exports to domestic sales, following the approach discussed in the previous section. Then, I examine the role of financial underdevelopment in distorting firm-level decisions by studying a set of key statistics for each of the parametrizations discussed in this section. Finally, I examine the response of equilibrium prices to changes in the magnitude of the financial frictions featured by the model.

Trade openness decomposition In Panel C, I report the ratio of exports to domestic sales across the different parametrizations of the model, along with the three terms in which it can be decomposed. Recall that, in the model, the ratio of exports to domestic sales is a simple monotonic transformation of the ratio of exports to GDP. I examine the contribution of each of these terms to the ratio of exports to domestic sales in turn.

On the one hand, I find that the share of firms that export and exporters' size relative to all 
Table 3: Financial development and international trade

Baseline No credit Frictionless Fixed $r$ and $w$

\begin{tabular}{|c|c|c|c|c|}
\hline \multicolumn{5}{|c|}{ A. Financial development and international trade } \\
\hline$\theta$ & 0.37 & 0.00 & $\infty$ & $\infty$ \\
\hline $\mathrm{X} / \mathrm{GDP}$ & 0.25 & 0.25 & 0.27 & 0.41 \\
\hline Credit / GDP & 0.50 & 0.00 & 1.11 & 1.98 \\
\hline \multicolumn{5}{|c|}{ B. Equilibrium prices } \\
\hline$w$ & 0.46 & 0.43 & 0.51 & 0.46 \\
\hline$r$ & 0.09 & 0.04 & 0.11 & 0.09 \\
\hline$P$ & 0.63 & 0.63 & 0.64 & 0.57 \\
\hline \multicolumn{5}{|c|}{ C. Trade openness decomposition } \\
\hline $\mathrm{X} / \mathrm{D}$ & 0.33 & 0.34 & 0.37 & 0.71 \\
\hline Relative size of exporters & 1.98 & 1.91 & 2.11 & 1.45 \\
\hline Share of firms that export & 0.21 & 0.21 & 0.26 & 0.53 \\
\hline Exporter-level X/D & 0.78 & 0.84 & 0.66 & 0.92 \\
\hline
\end{tabular}

firms selling domestically (whether they export or not) both increase with financial development. As financial constraints relax, a relatively larger set of firms can afford to pay the sunk export entry cost and, thus, choose to export.

Also, as financial constraints relax, financially constrained exporters and non-exporters are able to operate at a relatively higher scale. This increased scale raises their weight in the measure of aggregate relative size, by lowering $\mu_{\theta}$ for these firms. Given that exporters are relatively more productive and, thus, more likely to operate at a sub-optimal scale, the relaxation of financial constraints leads to a relatively higher increase in the scale of exporters. Therefore, $\mu_{\theta}$ decreases relatively more for exporters, and, thus, the aggregate scale, or productivity, of exporters is seen to increase relative to that of all domestic producers.

On the other hand, I find that the demand faced by firms in the foreign relative to the domestic 
market (the term denoted "exporter-level X/D") is decreasing in financial development. As discussed previously, as the economy's financial markets develop, its entrepreneurs are able to produce at a higher scale and make higher profits and, thus, demand relatively more final goods - for investment and consumption, as well as for the payment of sunk export entry costs. This increased demand for final goods leads to a relatively higher demand for the intermediate goods produced by entrepreneurs, thereby decreasing the ratio of exports to domestic sales at the firm level.

The overall response of the ratio of exports to domestic sales to the development of financial markets is given by the relative response of each of the forces that have been just described. This ratio increases to the extent that the share of exporters and their relative productivity increase more than the decrease in relative demand, and vice-versa. In the calibration of the model to the Chilean economy, I find that the response of each of these terms is similar in magnitude, thus leading to a very small change in the ratio in response to financial development.

Firm-level mechanics I now study the firm-level mechanism leading to the stark result that financial development does not lead to an increase in the ratio of exports to value added at the aggregate level. I report these results in Panels A and B of Table 4.

Panel A reports the response of international trade variables to the development of domestic financial markets. As discussed before, I find that, while the share of firms that export increases, the fraction of their total sales that is exported actually decreases. Interestingly, I also find that there is a change in the composition of firms that export - with the development of financial markets, a larger share of large firms (as measured by their total domestic sales) chooses to export. Specifically, 78-percent of firms in the 33th percentile export, while practically none of those smaller choose to do so. Thus, larger firms are relatively more productive than those exporting in the economy with financial constraints - this leads to an additional increase in the relative productivity of exporters, in addition to the boost coming from the relaxation of financial constraints.

Panel B reports a set of firm-level statistics related to the impact of financial constraints on firms' production and export decisions, which I study in turn. First, observe that financial constraints do have a significant impact on firms' production decisions: Around half of the firms in the baseline economy operate at a constrained scale (that is, their borrowing constraint is binding ${ }^{25}$ ), with this

\footnotetext{
${ }^{25}$ Note that, in this model, some firms may be operating at a constrained scale, and yet not have a binding financial constraint. Specifically, some firms may choose not to export due to the financial constraint, and yet operate at their
} 
being the case for all firms in the no-credit economy. Moreover, among those operating at a constrained scale, entrepreneurs in the baseline economy make, on average, 88-percent of the profits they would make if they were operating at their optimal scale, while this number is 75 -percent in the economy without credit. $^{26}$

The key mechanism through which financial constraints distort firms' export decisions is by delaying their decision to start exporting. In the baseline economy, firms take more than eight years, on average, to start exporting, with this number close to 12 in the economy without credit. In contrast, in the frictionless economy, all of the firms that end up eventually exporting, pay the sunk export entry cost upon birth, and start to export in their second year.

Another way to capture the role of financial frictions in distorting export entry, is by comparing the size of sunk export entry costs to the size of pre-entry internal funds (that is, their net worth), as well as to the rate at which non-exporters can increase these funds (that is, domestic profits and labor income). While the size of sunk export entry costs relative to the average level of net worth of non-exporters decreases with financial development, their size relative to the entrepreneurs' total income stays approximately constant. Two effects are in play here. First, with financial development, only the largest (and, thus, most productive) firms choose to export. Therefore, while the profits of non-exporters are higher than before financial development, the set of firms that end up being nonexporters has lower productivity and, thus, make lower profits. The second effect is the change in equilibrium prices. While the increase in the wage and interest rate lowers firms' profits, it raises the labor income of entrepreneurs.

In contrast to the case of non-exporters, financial development increases the average productivity of exporters, leading them to have higher profits, on average, relative to the profits they would earn if the pre-financial development set of firms was exporting. Yet, the size of sunk costs relative to average profits of exporters increases given the increase of the wage and interest rate. Thus, we also find that the size of sunk costs relative to the average net worth of exporters increases with financial development. Overall, however, their total income remains relatively constant given the higher labor income, as for non-exporters.

optimal scale in the domestic market. I abstract from these firms in this discussion.

${ }^{26}$ Recall that these are averages across all firms with binding financial constraints, and may not fully reflect the intensity of financial constraints for certain types of firms. For instance, high productivity firms are few, yet likely to be the most constrained ones, and may not be appropriately reflected in the measures reported. 
Table 4: Firm-level implications of financial development

Baseline No credit Frictionless Fixed $r$ and $w$

\section{A. International trade}

Share of firms that export

Avg export intensity (exports / total sales)

Export share, smallest third in domestic sales

Export share, middle third in domestic sales

Export share, largest third in domestic sales
0.21

0.44

0.00

0.07

0.56
0.21

0.46

0.00

0.11

0.51
0.26

0.40

0.53

0.48

0.00

0.00

0.00

0.69

0.78

0.90

\section{B. Financial constraints}

Fraction constrained

Profits (constrained / frictionless)

S / Avg non-exporter total income

S / Avg non-exporter profits

S / Avg non-exporter net worth

S / Avg exporter income

S / Avg exporter profits

S / Avg exporter net worth

Number of years before exporting

Exporters credit / Non-exporters credit
0.50

0.99

0.75

0.88

0.98

4.01

0.98

3.36

0.80

1.07

0.52

0.86

0.48

0.74

0.23

0.22

8.14

11.69

0.61
0.00

0.00

$-$

0.96

5.24

0.66

0.46

0.52

0.51

0.93

0.91

0.42

0.68

Finally, I find that financial development leads to an increase in the share of total credit exporters account - this is driven by the relative increase in the productivity of exporters, as well as by the slightly higher share of firms that choose to export.

Equilibrium prices The previous discussion suggests that the response of equilibrium prices plays a key role in offsetting the potential gains from financial development, both for firms that export and for those that are in the process of accumulating internal resources to start exporting. I now study the extent to which the response of the equilibrium wage and interest rate to the changes in financial 
development affect the aggregate response of exports relative to GDP. To do so, I compute the response of this ratio to a change in financial development, keeping the wage and the interest rate fixed at their values from the baseline pre-financial-development equilibrium - and, thus, not clearing the labor and financial markets. ${ }^{27}$ I report these results in the last column of Table 3.

One way to interpret these results in economic terms is that they represent the response of the ratio of exports to GDP to financial development in an industry that is small relative to the rest of the economy. In that context, the assumption that aggregate prices are fixed is standard in the literature. Thus, the comparison conducted in this subsection can be reinterpreted as contrasting the implications of financial development when this policy change impacts a small industry relative to its impact when it affects the aggregate economy. ${ }^{28}$

In contrast to the case in which aggregate prices adjust in response to financial development, I find that the ratio of exports to GDP increases substantially (by 64-percent, or 16 percentage points) when aggregate prices are kept fixed at their pre-financial-development level.

I examine the increase in the relative trade level through the lens of the decomposition of the exports to domestic sales ratio, contrasting it with the results from the case in which aggregate prices respond to the policy change.

First, observe that exporter X/D actually increases rather than decreases, when the wage and interest rate are kept fixed. Even though the quantity of the final good increases in response to financial development, its price decreases sharply due to the lower prices that firms are able to charge, since the wage and interest rate are lower than they would be in general equilibrium. Thus, the effective demand that firms face from the rest of the world relative to the domestic economy is higher after financial development, pushing the ratio of exports to domestic sales upwards.

Next, notice that there is a sharp increase in the share of firms that export. After financial development, 53-percent of firms export, in contrast to 26-percent in general equilibrium. As financial constraints are relaxed, the scale of entrepreneurs increases and so does their profits. Now, with aggregate prices fixed at their pre-financial-development level, this increase in profits is not offset by

\footnotetext{
${ }^{27}$ Given that the economy is open, the wage and interest rate can be kept fixed such that the labor and financial markets do not clear, while the market for final goods does clear. The latter clears through net inflows or outflows of goods, which are the counterpart to the no clearing of domestic financial markets.

${ }^{28} \mathrm{As}$ discussed in the presentation of the model, the assumption that the interest rate is fixed can also be interpreted as reflecting an environment in which entrepreneurs have access to international financial markets, at a fixed world interest rate $r$.
} 
the increase of aggregate prices. Thus, conditional on exporting, entrepreneurs' profits are higher with fixed prices - and, thus, are the returns obtained from starting to export.

The counterpart to the large increase in the share of firms that export, is that the size of exporters relative to non-exporters falls in response to financial development. On the one hand, as before, exporters are more likely to be financial constrained, and, thus, the decrease in $\mu_{\theta}$ is larger relative to that of non-exporters. On the other hand, however, all firms that found it profitable to export before financial development, continue to export - given that aggregate prices remain fixed, their profits unequivocally increase. These were relatively productive firms to start with. In addition to these firms, a large number of relatively more unproductive firms starts to export, pushing down the average productivity of exporters relative to all domestic firms. This can be observed in Panel A of Table 4, where all firms in the upper third of the size distribution choose to export, and around 69-percent in the middle third of the size distribution. ${ }^{29}$ This contrasts with the statistics from the frictionless economy in general equilibrium, where only 78-percent of the upper third of the size distribution export.

Overall, financial development leads to a sharp increase in the ratio of exports to domestic sales, largely driven by the increase in the share of exporters. Thus, I conclude that the response of aggregate prices to the increase in financial development is the crucial channel accounting for the almost negligible response of the relative volume of international trade to this policy change.

Finally, I contrast these results with those obtained when only one of the prices is kept fixed, either the wage or the interest rate - these results are not reported. I find that when only one of the prices is kept fixed, financial development leads to a small increase in the ratio of exports to GDP. In particular, considerably smaller than when both prices are fixed, and only marginally larger than when both are allowed to adjust to clear markets. The price that is allowed to adjust increases relatively more than in the environment when both are allowed to do so - this excess response of the flexible price accounts for the smaller distortion on exports to GDP, relative to the model in which both prices are fixed.

\subsection{Financial development, international trade, and aggregate output}

While financial development leads to a negligible increase in the relative volume of international trade, the development of financial markets unequivocally leads to an increase in the level of aggregate output

\footnotetext{
${ }^{29}$ Recall that, without financial constraints, firm size is only determined by its level of productivity. Also, note that, given that there is a one-period export entry delay and that the death and birth rates are ten percent, at most 90-percent of firms can export at any one time.
} 
Table 5: Financial development and aggregate output

\begin{tabular}{cccc}
\hline \hline & Baseline & No credit & Frictionless \\
& & & \\
\hline Real GDP & 1.44 & 1.36 & 1.59 \\
TFP & 1.15 & 1.12 & 1.20 \\
N & 1.00 & 1.00 & 1.00 \\
K & 2.00 & 1.79 & 2.34 \\
\hline \hline
\end{tabular}

and exports. In this section, I examine the implications of financial development for aggregate output. Note that, given that the level of international trade relative to output is approximately constant in response to this policy change, the change in the level of aggregate output also informs about the change in the level of international trade.

I report the implications of financial development for aggregate output and its decomposition into TFP, capital, and labor, as discussed in the previous section, in Table 5.

The level of real GDP increases by ten percent in response to financial development, with a slightly larger increase in the level of aggregate exports. Moreover, the level of output in the economy without financial frictions is 17 -percent larger than in the economy without credit. While not large relative to other findings in the literature, this is an economically significant increase in the level of output.

The increase in real GDP is driven by an increase in the level of TFP, as well as by an increase in the reproducible factors of production - namely, capital. Their relative contribution to the increase in real GDP is actually shared relatively evenly, with the increase in the aggregate capital stock having a slightly larger contribution. As discussed in the previous section, the increase in the level of TFP is driven by $(i)$ the relative increase in the scale of productive firms, which are those that are likely to be more constrained; and by $(i i)$ the slight increase in the share of firms that export. However, the increase in the aggregate capital stock is driven by the fact that firms can now accumulate capital much faster since they are not subject to the collateral constraint. This increase is relatively offset by the increase in the interest rate - that is, the cost at which firms are able to borrow to finance these investments. 


\section{Cross-Sectoral Implications}

In this section, I investigate the effect of financial development on the relative level of international trade at the sectoral level. Manova (forthcoming) and Beck (2003) document that sectors with higher "external financial dependence" 30 feature relatively higher international trade flows in countries that are more financially developed. I study the extent to which the model can account for this cross-sectoral relationship.

I extend the model to feature two sectors, $\mathrm{H}$ and $\mathrm{L}$, with measure $1 / 2$ of entrepreneurs in each sector. I follow Manova (forthcoming), in modeling the degree to which entrepreneurs can collateralize their assets to be sector-specific, with firms in sectors $\mathrm{H}$ and $\mathrm{L}$ able to pledge fractions $\theta_{H}$ and $\theta_{L}$ of their capital stock, respectively. I assume that $\theta_{H} \geq \theta_{L}$. The rest of the model follows as described in Section 2.

I use the model to examine the quantitative potential of financial underdevelopment to account for the cross-sectoral relationship between finance and international trade. Thus, I make the extreme assumption that sector $\mathrm{H}$ is not subject to a financial constraint $\left(\theta_{H}=\infty\right)$, and that sector $\mathrm{L}$ has no access to credit $\left(\theta_{L}=0\right)$. All other parameters are set to the values from Table 1 . The relative levels of international trade implied by this parametrization at both the sectoral and aggregate levels are reported in Table 6. I contrast the implications of this parametrization of the model, with those of a model in which none of the sectors is subject to a financial constraint $\left(\theta_{H}=\theta_{L}=\infty\right)$.

On the one hand, I find that the model with cross-sectoral heterogeneity in $\theta$ implies large differences in the relative level of international trade at the sectoral level. While sector L only exports $12 \%$ of total sectoral output, sector $\mathrm{H}$ exports $29 \%$ of it - a ratio that is more than twice as large. Moreover, while only $10 \%$ of firms export in sector L, more than half of them do so in sector $\mathrm{H}$.

On the other hand, I find that, while financial development leads to large changes in the relative level of international trade at the sectoral level, it leads to considerably smaller changes at the aggregate level. Specifically, with financial development, the financial constraint in sector L is fully relaxed $\left(\theta_{L}=\infty\right)$, which leads to a more than doubling in the sectoral ratio of exports to total output. Given that the ratio of exports to GDP in sector $\mathrm{H}$ decreases, the ratio of exports to GDP at the aggregate level increases by considerably less than in sector L. These changes are mirrored, and driven, by the

\footnotetext{
${ }^{30}$ Defined as the share of capital expenditures not financed with cash flows from operations. For details, see Rajan and Zingales (1998).
} 


\section{Table 6: Cross-sectoral implications of financial development on international trade}

\begin{tabular}{c|cc|cc}
\hline \hline & $X / G D P$ & Share of exporters \\
& & & \\
& $\theta_{L}=0$ & $\theta_{L}=\infty$ & $\theta_{L}=0$ & $\theta_{L}=\infty$ \\
& & & & \\
Sector L & 0.12 & 0.27 & 0.10 & 0.24 \\
Sector H & 0.29 & 0.27 & 0.50 & 0.24 \\
Aggregate & 0.23 & 0.27 & 0.30 & 0.24 \\
& \multicolumn{4}{|l}{} \\
\hline \hline
\end{tabular}

changes in the share of exporters. While sector L increases its share of exporters from $10 \%$ to $24 \%$, sector $\mathrm{H}$ decreases its share of exporters from $50 \%$ to $24 \%$.

These findings show that, even though financial development leads to very small increases in the relative level of international trade at the aggregate level, it can lead to relatively larger changes at the sectoral level. Thus, they suggest that, while financial underdevelopment may distort the relative level of trade at the sectoral level, these need not lead to distortions at the aggregate level.

\section{Conclusion}

In this paper, I have evaluated the potential of distortions of firms' export decisions due to financial constraints to account for the empirical relationship between financial development and the relative volume of international trade that has been documented at the aggregate level. I studied a model of international trade with heterogeneous firms subject to a financial constraint. I disciplined the model using firm-level data for Chilean manufactures, finding that financial development does not necessarily lead to an increase in the relative level of international trade. Even though the relaxation of the financial constraints allows more firms to trade internationally, input prices increase in equilibrium, thereby reducing the returns from becoming an exporter. To the extent that prices remain fixed, financial development can have a significant impact on the relative level of international trade. Thus, while financial underdevelopment may distort the relative level of trade at the sectoral level, it need not lead to distortions at the aggregate level. 


\section{References}

Alessandria, G., And H. Choi (2012): "Establishment Heterogeneity, Exporter Dynamics, and the Effects of Trade Liberalization," Working Paper.

Anderson, J. E., And E. VAn Wincoop (2004): "Trade Costs," Journal of Economic Literature, $42(3), 691-751$.

Beck, T. (2002): "Financial Development and International Trade: Is There a Link?," Journal of International Economics, 57(1), 107-131.

(2003): "Financial Dependence and International Trade," Review of International Economics, $11(2), 296-316$.

Bellone, F., P. Musso, L. Nesta, and S. Schiavo (2010): "Financial Constraints and Firm Export Behaviour," The World Economy, 33(3), 347-373.

Buera, F. J., J. P. Kaboski, And Y. Shin (2011): "Finance and Development: A Tale of Two Sectors," American Economic Review, 101, 1964-2002.

Buera, F. J., And B. Moll (2012): "Aggregate Implications of a Credit Crunch," Working Paper.

Carroll, C. (2006): "The Method of Endogenous Gridpoints for Solving Dynamic Stochastic Optimization Problems," Economics Letters, 91(3), 312-320.

Chaney, T. (2008): "Distorted Gravity: The Intensive and Extensive Margins of International Trade," American Economic Review, 98(4), 1707-1721.

Gross, T., And S. Verani (2012): "Financing Constraints, Firm Dynamics and International Trade," Working Paper.

Heer, B., And A. Maussner (2005): Dynamic General Equilbirum Modelling. Springer.

Kohn, D., F. Leibovici, And M. Szkup (2012): "Financial Frictions and New Exporter Dynamics," Working Paper, New York University.

Manova, K. (forthcoming): "Credit Constraints, Heterogeneous Firms, and International Trade," Review of Economic Studies.

Melitz, M. J. (2003): "The Impact of Trade on Intra-Industry Reallocations and Aggregate Industry Productivity," Econometrica, 71(6), 1695-1725.

Midrigan, V., And D. Y. Xu (2012): "Finance and Misallocation: Evidence from Plant-Level Data," Working Paper, New York University.

Minetti, R., and S. Zhu (2011): "Credit Constraints and Firm Export: Microeconomic Evidence from Italy," Journal of International Economics, 83(2), 1695-1725.

Rajan, R. G., and L. Zingales (1998): "Financial Dependence and Growth," American Economic Review, 88(3), 559-586.

Suwantaradon, R. (2012): "Financial Frictions and International Trade," School of Economics, Singapore Management University. 